\title{
Antimicrobial Activity of Culture Filtrate of Bacillus amyloliquefaciens RC-2 Isolated from Mulberry Leaves
}

\author{
S. Yoshida, S. Hiradate, T. Tsukamoto, K. Hatakeda, and A. Shirata
}

\begin{abstract}
First and second authors: National Institute of Agro-Environmental Sciences, 3-1-1 Kan-nondai, Tsukuba, Ibaraki 305-8604, Japan; third author: Yokohama Plant Protection Service, 5-57 Nakaku, Kitanakadori, Yokohama 231-0003, Japan; fourth author: Tohoku National Industrial Research Institute, 4-2-1 Nigatake, Miyagino-ku, Sendai 983-8551, Japan; fifth author: National Institute of Sericultural and Entomological Science, 1-2 Owashi, Tsukuba, Ibaraki 305-8634, Japan.
\end{abstract} Accepted for publication 26 October 2000.

\section{ABSTRACT}

Yoshida, S., Hiradate, S., Tsukamoto, T., Hatakeda, K., and Shirata, A. 2001. Antimicrobial activity of culture filtrate of Bacillus amyloliquefaciens RC-2 isolated from mulberry leaves. Phytopathology 91:181-187.

A potential antagonist, Bacillus amyloliquefaciens strain RC-2, against Colletotrichum dematium, mulberry anthracnose fungus, was obtained from healthy mulberry leaves by in vitro and in vivo screening techniques. Application of culture filtrate of RC-2 inhibited disease on mulberry leaves, indicating that suppression was due to antifungal compounds in the filtrate. Development of mulberry anthracnose on mulberry leaves was inhibited only when the culture filtrate was applied before fungal inoculation, and it was not inhibited by application after inoculation. These results suggest that the antifungal compounds in the filtrate exhibit a preventive effect on the disease. Peptone significantly increased production of the antifungal compounds. The culture filtrate of RC-2 also inhibited the growth of several other phytopathogenic fungi and bacteria, such as Rosellinia necatrix, Pyricularia oryzae, Agrobacterium tumefaciens, and Xanthomonas campestris pv. campestris, in vitro. From the culture filtrate of RC-2, seven kinds of antifungal compounds were isolated by high performance liquid chromatography analysis, and one of the compounds was determined as iturin A2, a cyclic peptide, by nuclear magnetic resonance and fast atom bombardment mass analysis.
Mulberry anthracnose, caused by Colletotrichum dematium (Persoon: Fries) Grove, is a disease commonly observed in mulberry fields in Japan (29). The symptoms of the disease consist of brown to red necrotic spots or streaks on the leaves of the tree from early summer to autumn $(28,29)$, leading to a loss of yield of leaves for silkworm feeding. The infected leaves that fall in the field are a source of primary inoculum in the following year (30). Recently, the incidence of this disease has increased, due to dense planting of the trees and mechanical harvesting of the shoots, which results in significant damage to tree vigor. Control of the disease has been a major problem in mulberry cultivation.

Although the fungicide thiophanate-methyl (1,2-bis[3-methoxycarbonyl-2-thioureido]benzene) has been widely used (11), integrated control of anthracnose disease including chemical and biological control is important from an ecological and economical point of view. Biological control has been attempted with various microorganisms (2), and a variety of antagonistic actions are involved (1). Biocontrol studies by antagonistic microorganisms, however, have not been performed on mulberry anthracnose.

The first objective of this study was to isolate microorganisms that inhibit the anthracnose disease as biocontrol agents. Emphasis was placed on the isolation of Bacillus spp., because members of this genus have been frequently isolated from healthy mulberry leaves and have been reported to be a biocontrol agent in other plant diseases $(3,17,23,25)$. Indeed, it has been reported that Bacillus has the potential for biological control of several tree diseases (22,23). Bacillus has also been observed to inhibit a few Colletotrichum spp. in vitro $(5,10)$ and in vivo $(5)$, but not $C$. dematium.

Corresponding author: S. Yoshida; E-mail address: yoshige@niaes.affrc.go.jp

Publication no. P-2000-1127-03R

(c) 2001 The American Phytopathological Society
Once the bacterial strain RC-2, isolated from healthy mulberry leaves, strongly inhibited the disease owing to the production of antifungal compounds, the next objectives were to verify the incubation conditions suitable for the production of the compounds, estimate their antimicrobial spectrum, and isolate and identify the antifungal compounds.

\section{MATERIALS AND METHODS}

Media. Solid media used in the study consisted of potato sucrose agar (PSA: potato, $200 \mathrm{~g}$; sucrose, $20 \mathrm{~g}$; agar, $18 \mathrm{~g}$; and distilled water, 1 liter), potato semisynthetic agar (PSSA: potato, $300 \mathrm{~g}$; $\mathrm{Ca}\left(\mathrm{NO}_{3}\right)_{2} \cdot 4 \mathrm{H}_{2} \mathrm{O}, 0.5 \mathrm{~g} ; \mathrm{Na}_{2} \mathrm{HPO}_{4} \cdot 12 \mathrm{H}_{2} \mathrm{O}, 2 \mathrm{~g}$; polypeptone, $5 \mathrm{~g}$; sucrose, $15 \mathrm{~g}$; agar, $18 \mathrm{~g}$; and distilled water, 1 liter), and LuriaBertani agar (LBA: bactotryptone, $10 \mathrm{~g}$; yeast extracts, $5 \mathrm{~g}$; $\mathrm{NaCl}$, $10 \mathrm{~g}$; agar, $18 \mathrm{~g}$; and distilled water, 1 liter). The same medialacking agar (PS, PSS, and LB, respectively) were also used as liquid media. Other liquid media used were potato dextrose medium (PD: potato, $200 \mathrm{~g}$; dextrose, $20 \mathrm{~g}$; and distilled water, 1 liter), King's medium B (KB: proteose peptone No. 3, $20 \mathrm{~g} ; \mathrm{K}_{2} \mathrm{HPO}_{4}$, $1.5 \mathrm{~g} ; \mathrm{MgSO}_{4}, 1.5 \mathrm{~g}$, glycerin, $10 \mathrm{ml}$; and distilled water, 1 liter), and $0.5 \%$ peptone-PD medium $(0.5 \%$ PPD: polypeptone, $5 \mathrm{~g}$; potato, $200 \mathrm{~g}$; dextrose, $20 \mathrm{~g}$; and distilled water, 1 liter).

Isolation and screening of bacteria showing antifungal activity from mulberry leaves. Healthy leaves from several mulberry cultivars attached to the trees in the field at the National Institute of Sericultural and Entomological Science, Tsukuba, were sampled in October 1995. Two or three segments $\left(0.5\right.$ to $\left.1 \mathrm{~cm}^{2}\right)$ randomly cut out from each leaf were suspended in sterile distilled water in a glass tube with smashing by a small knife. Aliquots $(100 \mu \mathrm{l})$ of a dilution of each suspension were spread on PSA or PSSA plates. After incubation for 1 to 2 days at $40^{\circ} \mathrm{C}$ in the dark, bacteria, particularly Bacillus spp., appeared on the plates and were individually isolated as a single colony on PSA or PSSA. Each isolate was transferred to a PSA plate on which was placed a 
mycelial block (8 to $10 \mathrm{~mm}^{3}$ ) of $C$. dematium (strain S8901) (31). Bacteria were approximately $3 \mathrm{~cm}$ from the block. After incubation for 4 to 7 days under ambient conditions, 17 bacterial isolates that markedly inhibited the fungal growth were selected. Selected isolates were transferred individually to $10 \mathrm{ml}$ of PS liquid medium in a 100-ml Erlenmeyer flask and incubated by shaking each culture at $100 \mathrm{rpm}$ (Double Shaker NR-30, Taitec, Koshigaya) for 2 days under ambient conditions. Inhibition activity against $C$. dematium by the resulting bacterial suspensions was assayed with mulberry seedlings (cv. Ichinose; Morus alba L.) that were each produced in a plastic pot $\left(125 \mathrm{~cm}^{3}\right)$. Each bacterial suspension was spread with an artist's brush on both surfaces of all the leaves (three to four leaves per seedling) of two mulberry seedlings (approximately $10^{9} \mathrm{CFU}$ per leaf). After airdrying, the seedlings were spray-inoculated with a conidial suspension $\left(5 \times 10^{5}\right.$ conidia per $\left.\mathrm{ml}\right)$ of $C$. dematium prepared as previously described (30), incubated in a moist chamber for 3 days at $25^{\circ} \mathrm{C}$, and maintained for 5 days in a greenhouse (approximately 12 -h daylight) at 23 to $25^{\circ} \mathrm{C}$. From this screening, bacterial strain RC-2, which was most inhibitory to development of the anthracnose symptoms for further evaluation, was selected. Strain RC-2 was identified using API 50 CHB test strip (Bio Merieux S.A., France) $(12,13,15)$.

Disease inhibition by strain RC-2 on mulberry leaves. Strain $\mathrm{RC}-2$ was grown in $0.5 \%$ PPD liquid medium $(50 \mathrm{ml})$ in a $300-\mathrm{ml}$ Erlenmeyer flask for 2 days, with shaking as described above. Fifteen-milliliter aliquots of the culture were transferred to a $50-\mathrm{ml}$ tube, and the culture filtrate was obtained by centrifugation at $3,000 \times g$ for $10 \mathrm{~min}$. The pellet of the bacterial cells obtained by the centrifugation was washed twice by resuspension in distilled water and centrifugation $(3,000 \times g$ for $10 \mathrm{~min})$. A suspension $(15 \mathrm{ml})$ of washed bacterial cells, approximately $10^{9} \mathrm{CFU} / \mathrm{ml}$, was made.

Young mulberry trees (cv. Shin-Ichinose, M. alba) used in the experiment were individually produced in plastic pots $(16 \mathrm{~cm}$ in diameter, $20 \mathrm{~cm}$ high) and grown in a greenhouse until 13 to 15 leaves had developed. Four trees were used in the test. On two randomly selected leaves of each tree, the culture filtrate, washed bacterial cells, or the original incubation mixture of RC-2 was individually spread with an artist's brush.

After all surfaces of the treated leaves were air-died, a filter paper $(8 \mathrm{~mm}$ in diameter) soaked in a conidial suspension $(2.5 \times$ $10^{6}$ conidia per $\mathrm{ml}$ ) of $C$. dematium, prepared as described above, was placed on the adaxial surface of each treated leaf. Papers were also placed on two nontreated and two $0.5 \%$ PPD broth-treated leaves as controls. The inoculated trees were incubated in a moist chamber for 3 days at $25^{\circ} \mathrm{C}$ and maintained for 2 days in a greenhouse (approximately 12-h daylight) at 23 to $25^{\circ} \mathrm{C}$. Five days after inoculation, disease inhibition by treatment with each component of RC-2 (filtrate, washed bacterial cells, and incubation mixture) was observed. Disease incidence was evaluated based on the diameter of round anthracnose lesions that emerged under the filter papers on leaves. The diameter of lesions was measured by removing the filter papers. The test had eight replicates and was repeated twice.

Disease inhibition by culture filtrate from strain RC-2 treated before and after fungal inoculation. An experiment was performed to verify whether culture filtrate of RC-2 inhibited the anthracnose disease on mulberry leaves by applying before and after inoculation with $C$. dematium. Healthy mature mulberry leaves grown under the conditions described above were cut into squares (approximately $2 \times 2 \mathrm{~cm}$ ). On the upper surface of leaf squares, culture filtrate of RC-2 was spread with an artist's brush. Noncultured $0.5 \%$ PPD broth was also spread on other leaf squares as a control, and leaves were air-dried. Treatment of the filtrate and the medium was performed $5,3,1$, or 0 days before, or 1 day after inoculation with $10 \mu \mathrm{l}$ of a conidial suspension of $C$. dematium $\left(2.5 \times 10^{6}\right.$ conidia per $\left.\mathrm{ml}\right)$. During the experiment, the cut leaves were maintained in a moist chamber at $20^{\circ} \mathrm{C}$ before fungal inoculation and incubated at room temperature $\left(23\right.$ to $\left.25^{\circ} \mathrm{C}\right)$ after the inoculation. After 6 days of incubation, disease inhibition activity by the filtrate was observed, and disease incidence was evaluated based on the diameter of round anthracnose lesions on leaves. The experiment had five replicates and was repeated three times.

TABLE 1. Antimicrobial activity of the culture filtrate of Bacillus amyloliquefaciens RC-2

\begin{tabular}{|c|c|c|c|c|}
\hline \multirow[b]{2}{*}{ Microorganisms $^{\mathrm{a}}$} & \multicolumn{4}{|c|}{ Dilution of culture filtrate $^{b}$} \\
\hline & Onefold & Twofold & Fourfold & Control $^{\mathrm{c}}$ \\
\hline \multicolumn{5}{|l|}{ Bacteria $^{\mathrm{d}}$} \\
\hline Agrobacterium tumefaciens & $26.7 \pm 1.0$ & $22.7 \pm 1.0$ & $19.7 \pm 0.7$ & $\mathrm{NI}$ \\
\hline Clavibacter michiganensis subsp. michiganensis & $12.0 \pm 0.5$ & $7.3 \pm 1.0$ & $5.7 \pm 0.3$ & NI \\
\hline Erwinia carotovora subsp. carotovora & $16.0 \pm 0.5$ & $13.3 \pm 0.3$ & $9.7 \pm 0.3$ & NI \\
\hline Pseudomonas cichorii & $7.7 \pm 0.7$ & $2.7 \pm 1.2$ & NI & NI \\
\hline Pseudomonas marginalis pv. marginalis & $9.0 \pm 0.5$ & $5.3 \pm 0.3$ & $\mathrm{NI}$ & NI \\
\hline Pseudomonas syringae pv. mori & $13.0 \pm 0.9$ & $6.7 \pm 0.7$ & $\mathrm{NI}$ & NI \\
\hline Pseudomonas tolaasii & $7.7 \pm 1.1$ & $4.3 \pm 1.8$ & $\mathrm{NI}$ & NI \\
\hline Pseudomonas viridiflava & $10.7 \pm 0.3$ & $6.3 \pm 0.5$ & NI & NI \\
\hline Xanthomonas campestris pv. campestris & 25.0 & $21.0 \pm 0.5$ & $16.3 \pm 0.7$ & NI \\
\hline \multicolumn{5}{|l|}{ Fungie } \\
\hline Bipolaris leersiae & NG & NG & $3.0 \pm 1.3$ & $34.3 \pm 1.8$ \\
\hline Colletotrichum acutatum & NG & NG & $5.0 \pm 2.6$ & $30.3 \pm 0.3$ \\
\hline Colletotrichum dematium & NG & NG & NG & $20.3 \pm 1.0$ \\
\hline Diaporthe nomurai & NG & NG & $1.7 \pm 1.4$ & $29.7 \pm 1.5$ \\
\hline Fusarium lateritium f.sp. mori & $2.0 \pm 0.9$ & $7.0 \pm 1.4$ & $15.0 \pm 0.5$ & $23.7 \pm 0.5$ \\
\hline Glomerella cingulata & NG & NG & NG & $40.3 \pm 0.3$ \\
\hline Myrothecium roridum & NG & $1.0 \pm 0.8$ & $10.7 \pm 0.7$ & 15.0 \\
\hline Pyricularia oryzae & NG & NG & NG & $18.3 \pm 0.3$ \\
\hline Rosellinia necatrix & NG & NG & NG & $23.7 \pm 1.5$ \\
\hline Sclerotinia sclerotiorum & NG & NG & $13.7 \pm 5.6$ & $>90$ \\
\hline
\end{tabular}

a All isolates were preserved in our laboratory.

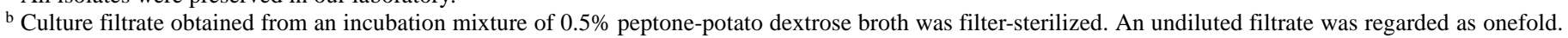
Twenty microliters of each dilution was placed on each bacterial layer or mycelial block.

c Sterilized distilled water $(20 \mu \mathrm{l})$ was placed as control.

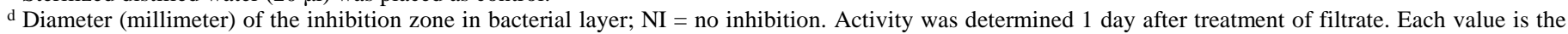
mean of three replicates. Variance is given as the standard error of the mean.

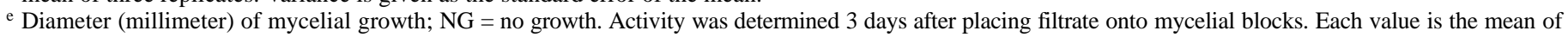
three replicates. Variance is given as the standard error of the mean. 
Incubation media for the production of the antifungal compounds by strain RC-2. To determine the incubation media for obtaining the most active culture filtrate, strain RC-2 was incubated with $10 \mathrm{ml}$ of PS, PD, KB, LB, PSS, or $0.5 \%$ PPD broth in a 100 -ml Erlenmeyer flask with shaking (130 rpm) for 2 days at $25^{\circ} \mathrm{C}$ in the dark. Approximately $1 \mathrm{ml}$ of culture filtrate from each incubation mixture was obtained by centrifugation at $8,000 \times g$ for $10 \mathrm{~min}$ and filter $(0.45 \mu \mathrm{m})$ sterilization. The aseptic filtrate $(20 \mu \mathrm{l})$ was placed onto a small mycelial block $\left(0.5\right.$ to $\left.1 \mathrm{~mm}^{3}\right)$ of $C$. dematium placed on a PSA plate. Twofold, fourfold, and eightfold dilutions of the filtrate in sterile distilled water were likewise each placed onto another mycelial block. After incubation for 3 days at $25^{\circ} \mathrm{C}$ in the dark, antifungal activity of each filtrate was evaluated by the diameter of the mycelial colony developed from the mycelial block (placing assay). Two replicates of each diameter were analyzed, and the experiment was repeated twice.

Antifungal activity of culture filtrate of strain RC-2 corresponding to bacterial growth. A bacterial suspension $(150 \mu \mathrm{l})$ of strain RC-2, approximately $10^{8} \mathrm{CFU} / \mathrm{ml}$, was transferred to $0.5 \%$ PPD broth $(15 \mathrm{ml})$ in a $100-\mathrm{ml}$ Erlenmeyer flask and incubated with shaking $(130 \mathrm{rpm})$ at $25^{\circ} \mathrm{C}$ in the dark. Aliquots $(100 \mu \mathrm{l})$ of incubation mixture were periodically removed from the same flask and placed in $0.9 \mathrm{ml}$ of sterile distilled water. If necessary, bacterial suspensions were serially diluted with sterile distilled water before spreading on LBA plates with a spreader. Viable cell numbers of RC-2 during the incubation were determined in terms of CFU on LBA plates. Two plates were used per dilution. Plates were incubated for 1 day at $40^{\circ} \mathrm{C}$ in the dark, and the white-wrinkled colonies of RC-2 were counted. The number of CFU in each incubation period was evaluated based on the average number of colonies developing on two plates. Simultaneously, additional $100-\mu \mathrm{l}$ aliquots of each periodic incubation mixture were sampled from the flask into a $1.5-\mathrm{ml}$ microtube and autoclaved $\left(121^{\circ} \mathrm{C}\right.$, $15 \mathrm{~min}$ ) to obtain a bacterial-free solution. The antifungal activity of each aseptic solution $(20 \mu \mathrm{l})$ and its serial twofold dilutions in sterile distilled water against $C$. dematium was assessed by the placing assay. A relative antifungal activity (RAA) that corresponds to relative concentration of total antifungal agents, was defined as follows. When maximum dilution ratios of the filtrate showing complete inhibition in mycelial growth by the placing assay were 1,2 , or 4 , the RAA values were scored as 1,2 , or 4, respectively. The experiment had three replicates and was repeated once.

Inhibition of conidial germination of $C$. dematium by the culture filtrate of RC-2. Twofold dilution series of a filtersterilized culture filtrate of RC-2 were obtained from $0.5 \%$ PPD cultures as described previously, and each dilution $(10 \mu \mathrm{l})$ was placed into two round depressions of a depression slide glass. Ten microliters of sterile distilled water was placed into two depressions of another glass as a control. Then, $10 \mu \mathrm{l}$ of a conidial suspension $\left(5 \times 10^{5}\right.$ conidia per $\left.\mathrm{ml}\right)$ of $C$. dematium was placed into each depression on the glasses. To increase conidial germination, $5 \mu \mathrm{l}$ of water soluble mulberry leaf components (27) was added to each depression, and depressions were incubated in a moist chamber at $25^{\circ} \mathrm{C}$ in the dark. After $20 \mathrm{~h}$ of incubation, approximately 200 conidia in each depression were evaluated for germination. The two depressions on each slide were considered subsamples, and treatments were replicated three times. The test was repeated once.

Antimicrobial spectrum of culture filtrate from strain RC-2. The activity of culture filtrate from RC-2 against 9 phytopathogenic bacteria and 10 phytopathogenic fungi was evaluated (Table 1). For bacteria, $2 \mathrm{ml}$ of each bacterial suspension (approximately $10^{9} \mathrm{CFU} / \mathrm{ml}$ ) was mixed with $10 \mathrm{ml}$ of PSSA at $55^{\circ} \mathrm{C}$, and the mixture was immediately poured in a $9-\mathrm{cm}$ diameter petri dish. After solidification, four sterilized stainless cylinders (5-mm internal diameter and 10-mm high) were equidistantly placed open end up on each plate. Filter-sterilized culture filtrate $(20 \mu \mathrm{l})$ of
RC-2 obtained by shake culturing in $0.5 \%$ PPD broth for 2 days and centrifuging as described above was added to the cylinder on each bacterial plate. Serial twofold dilutions of the filtrate were also each added to another cylinder. Twenty-four hours after incubation at $25^{\circ} \mathrm{C}$ in the dark, the diameter of a round inhibition zone of the bacterial growth was recorded. In the assay with fungi, four small mycelial blocks $\left(0.5\right.$ to $\left.1 \mathrm{~mm}^{3}\right)$ of each fungus were placed on a PSA plate equidistantly. The antifungal activity of the above filter-sterilized filtrate of $\mathrm{RC}-2$ or each dilution $(20 \mu \mathrm{l})$ was assayed by placing onto each mycelial block (placing assay). The test had three replicates and was repeated once.

Data analysis. The above experiments with RC-2 were conducted at least two times with similar results, and the data from single trials are presented here. Data on the inhibition activity of anthracnose disease by several components of RC-2 and the inhibition test of $C$. dematium growth by several culture filtrates of RC-2 were analyzed by Tukey's test. Data of the disease inhibition activity by culture filtrate of RC-2 applied before and after fungal inoculation were analyzed by Mann-Whitney's U test.

Chemical isolation and determination of antifungal compounds in culture filtrate of strain RC-2. For activity-directed purification, specific inhibition activity of the antifungal compounds was verified by the placing assay. Each fractionated sample $(20 \mu \mathrm{l})$, diluted to appropriate dilutions with $50 \%$ methanol, was placed onto each small mycelial block of $C$. dematium on PSA plates, and the antifungal activity was determined as described previously. Placing a drop $(20 \mu \mathrm{l})$ of $50 \%$ methanol solution (only a solvent) did not affect the fungal growth.

The culture filtrate of RC-2 used for the isolation of antifungal compounds was obtained by shaking the bacteria in $0.5 \%$ PPD broth and centrifuging as described above. Figure 1 shows the

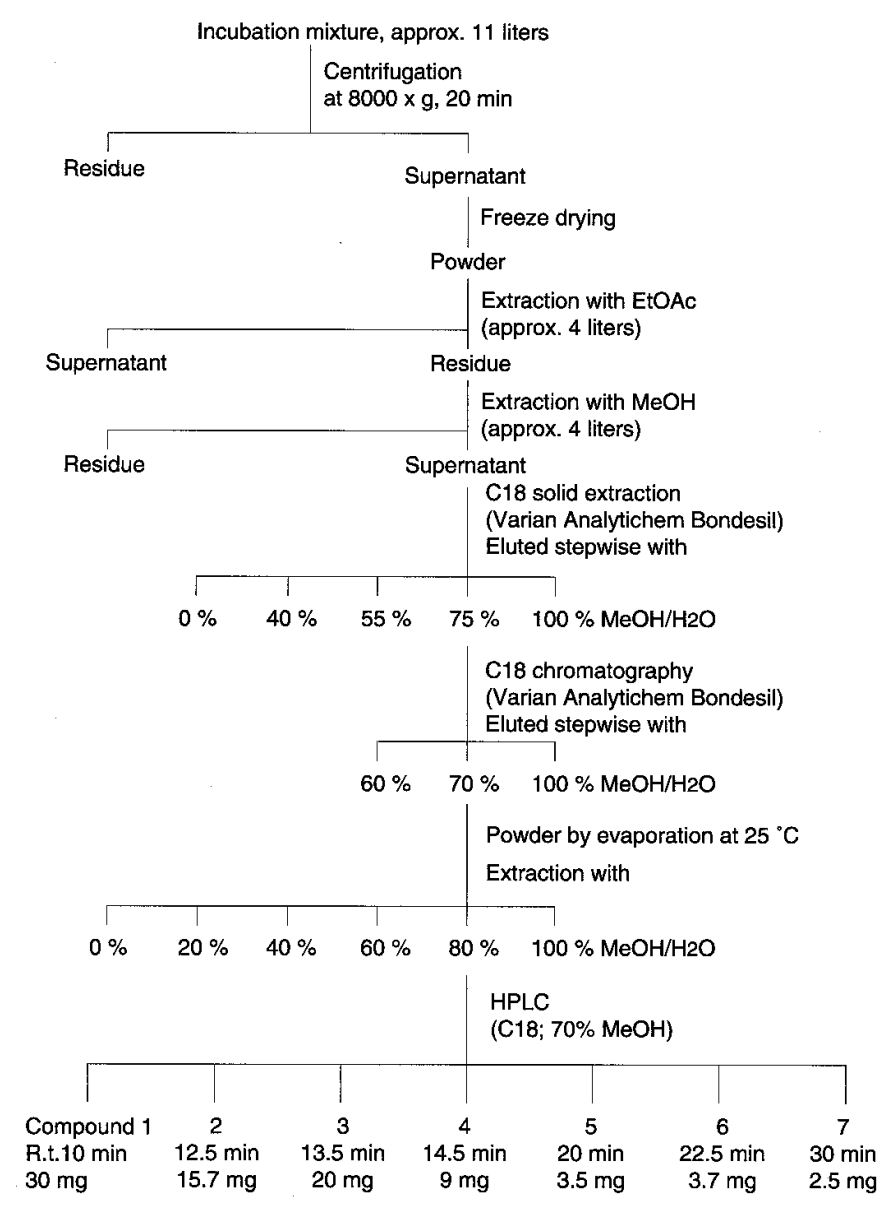

Fig. 1. Isolation procedure for antifungal compounds from culture filtrate of Bacillus amyloliquefaciens RC-2. 
isolation procedure for antifungal compounds from the lyophilized culture filtrate of RC-2. Approximately $60 \mathrm{~g}$ of lyophilized filtrate prepared from the culture filtrate was extracted with ethyl acetate, and the residue was extracted with methanol. The supernatant of the methanol extract showed strong inhibitory activity against $C$. dematium. The supernatant was air-dried and applied to a glass column $(200 \times 22 \mathrm{~mm}$ internal diameter $)$ packed with a reversed phase packing material (Analytichem Bondesil C18 PART12213012; Varian, Harbor City, CA). The active fraction was reapplied to the same column and evaporated and extracted with methanol, methanol/water, and finally with water. The most active fraction was fractionated by high performance liquid chromatography (HPLC) (626 pump with 996 photodiode array detector; Waters, Milford, MA) equipped with an analytical (Shodex C18-5B column, $250 \times 4.6 \mathrm{~mm}$ internal diameter; Showadenko, Tokyo) or a preparative (Shim-pack PREP-ODS column, $250 \times 20 \mathrm{~mm}$ internal diameter; Shimadzu, Tokyo) grade of reversed phase column at a flow rate of $1 \mathrm{ml} / \mathrm{min}$ or $8 \mathrm{ml} / \mathrm{min}$ at $40^{\circ} \mathrm{C}$, respectively. Samples eluted from the HPLC were collected at every 1-min interval. Antifungal activity of the collected samples was determined by the placing assay as described.

Nuclear magnetic resonance (NMR) spectra of isolated compounds was obtained by JNM A600 FT-NMR System (JEOL, Tokyo) in dimethyl sulfoxide solution, and fast atom bombardment mass (FAB-MS) spectra were measured using JNS SX 120A (JEOL).

\section{RESULTS}

Identification of strain RC-2. Based on colony and cell morphology, endospore formation and positive Gram staining (18), strain RC-2 was identified as Bacillus. Using the API tests and API LAB software package, strain RC-2 was identified as $B$. amyloliquefaciens (percentage of identity $=82.5 \% ; T$ index $=0.85$ ).

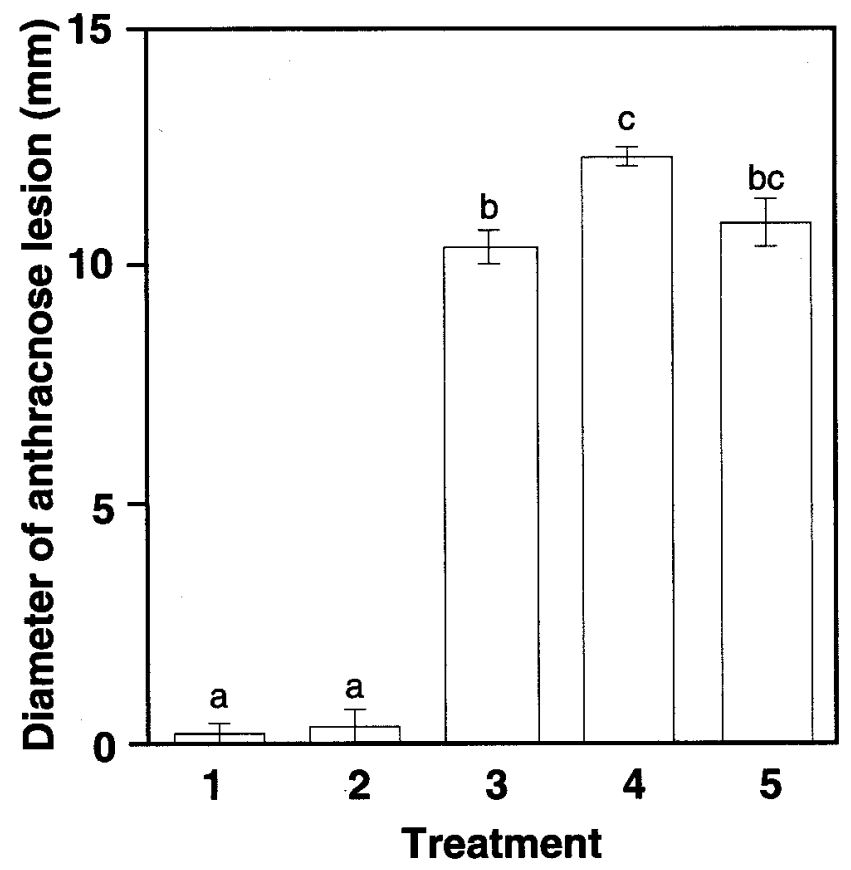

Fig. 2. Anthracnose disease on mulberry leaves treated with fractions of shake-cultured Bacillus amyloliquefaciens RC-2. Treatment 1, whole cell culture; treatment 2 , culture filtrate; treatment 3 , washed bacterial cells; treatment 4 , noncultured $0.5 \%$ peptone-potato dextrose broth (control); and treatment 5, no treatment (control). Leaves were treated $2 \mathrm{~h}$ before inoculation with a conidial suspension of Colletotrichum dematium. Each value represents the mean of eight replicates. Bars represent standard error of the mean. The same letters within each column are not significantly different $(P \leq 0.05)$ according to Tukey's test.
Disease inhibition by strain RC-2 on mulberry leaves. Figure 2 shows inhibition of anthracnose disease on leaves by each treatment of strain RC-2. Development of anthracnose lesions on leaves was significantly $(P \leq 0.05)$ inhibited by treatment with the liquid culture and the culture filtrate of RC-2. Both treatments completely inhibited anthracnose symptoms on almost all the treated leaves. Washed bacterial cells did not inhibit symptom development.

Disease inhibition by culture filtrate from strain RC-2 treated before and after fungal inoculation. Appearance of anthracnose symptoms was significantly $(P \leq 0.01)$ suppressed on the leaves spread with culture filtrate of $\mathrm{RC}-2$ for any period of days before fungal inoculation (Fig. 3), showing no symptoms on the leaves. Disease was not significantly $(P \geq 0.05)$ inhibited when the filtrate was applied after fungal inoculation.

Media for the production of the antifungal compounds by strain RC-2. The type of culture medium affected the antifungal activity of the culture filtrate (Fig. 4). Culture filtrates obtained from PSS and $0.5 \%$ PPD cultures completely inhibited mycelial growth, and filtrates diluted eightfold also strongly suppressed the growth. The undiluted filtrates obtained from PS and PD cultures significantly $(P \leq 0.05)$ suppressed growth compared with those obtained from $\overline{\mathrm{KB}}$ and $\mathrm{LB}$ cultures, although activity was lost when these were diluted fourfold to eightfold. Treatment of each noncultured medium alone did not influence fungal growth. Although a bacterial biomass in each incubation mixture was not precisely measured, PSS and $0.5 \%$ PPD appeared to encourage bacterial growth compared with the other media, based on the turbidity of their mixtures.

When RC-2 was incubated in three kinds of PPD broth containing peptone at $0.01,0.1$, or $0.5 \%$ for 2 days, the culture filtrate obtained from the $0.5 \%$ PPD cultures showed the strongest inhibition of mycelial growth of $C$. dematium.

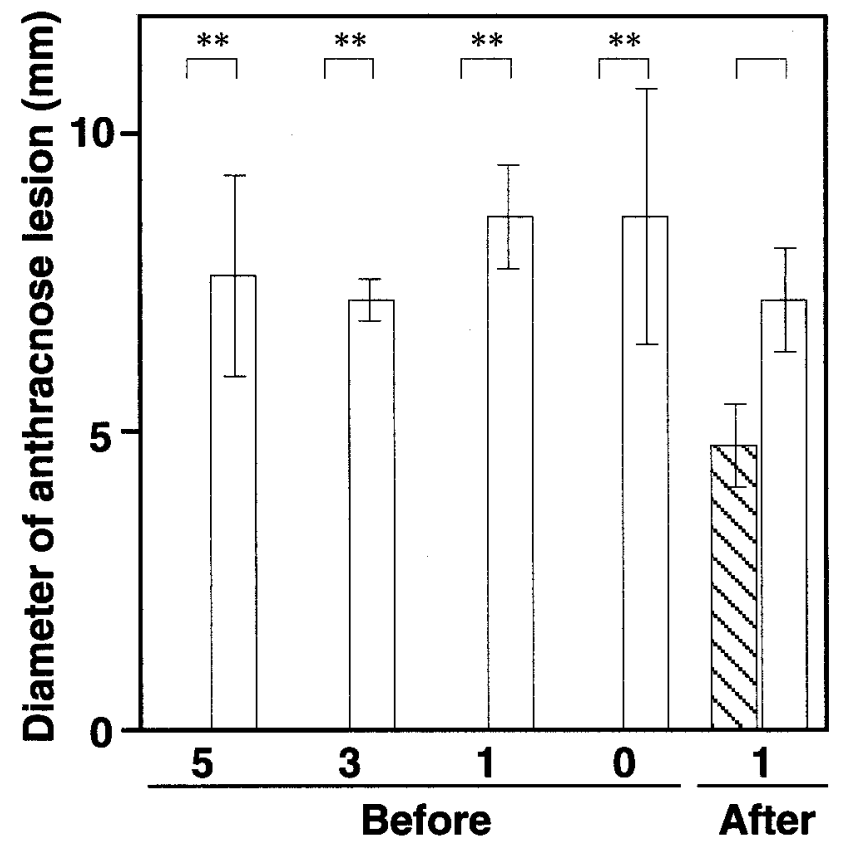

\section{Time (Days before or after pathogen inoculation)}

Fig. 3. Inhibition of anthracnose disease on mulberry leaves treated with culture filtrate of Bacillus amyloliquefaciens RC-2 before or after inoculation with Colletotrichum dematium. Lines indicate treatment with culture filtrate of RC-2. White indicates treatment with noncultured $0.5 \%$ peptone-potato dextrose broth (as control). Numerical values of both columns marked with asterisk are significantly different according to Mann-Whitney's U test (** = $P \leq 0.01)$. Each value represents the average of five replicates. Bars represent standard error of the mean. 
Antifungal activity of culture filtrate of strain RC-2 corresponding to bacterial growth. Figure 5 shows the viable cell number of RC-2 and the antifungal activity of the culture filtrate of RC-2 for each incubation time. The number of the cell logarithmically increased until 2 days after incubation when it declined to approximately $10^{9} \mathrm{CFU} / \mathrm{ml}$ until 3 days after incubation and remained almost steady until 12 days after incubation. On the other hand, antifungal activity of the filtrate was observed after $12 \mathrm{~h}$ of incubation. The activity increased rapidly until after 2 days of incubation, proportionally with the increase of the number of the cell. Subsequent incubation of the strain did not change the relative activity, and maximum activity against $C$. dematium was observed for the 12 days of incubation. Autoclaving did not influence the antifungal activity of the filtrate (data not shown).

Inhibition of conidial germination of $\boldsymbol{C}$. dematium by culture filtrate of RC-2. Figure 6 shows the germination rate of conidiasuspended dilutions of culture filtrate. No conidial germination was observed in the suspensions containing undiluted to 16-fold diluted culture filtrate. Further dilution (32-fold) of the filtrate strongly suppressed conidial germination, and germ tubes of the germinated conidia were shorter than those of the control (data not shown).

Antimicrobial spectrum of culture filtrate from strain RC-2. Filter-sterilized culture filtrate of RC-2 inhibited the growth of several phytopathogenic bacteria. The filtrate strongly inhibited the growth of Agrobacterium tumefaciens, Clavibacter michiganensis subsp. michiganensis, Erwinia carotovora subsp. carotovora, and Xanthomonas campestris pv. campestris (Table 1). These bacteria were even inhibited by fourfold dilutions of the filtrate. Growth of five species of Pseudomonas was less inhibited. Growth inhibition by the filtrate was also observed with the phytopathogenic fungi, and the growth of $C$. dematium and Glomerella cingulata (mulberry anthracnose fungus), Pyricularia

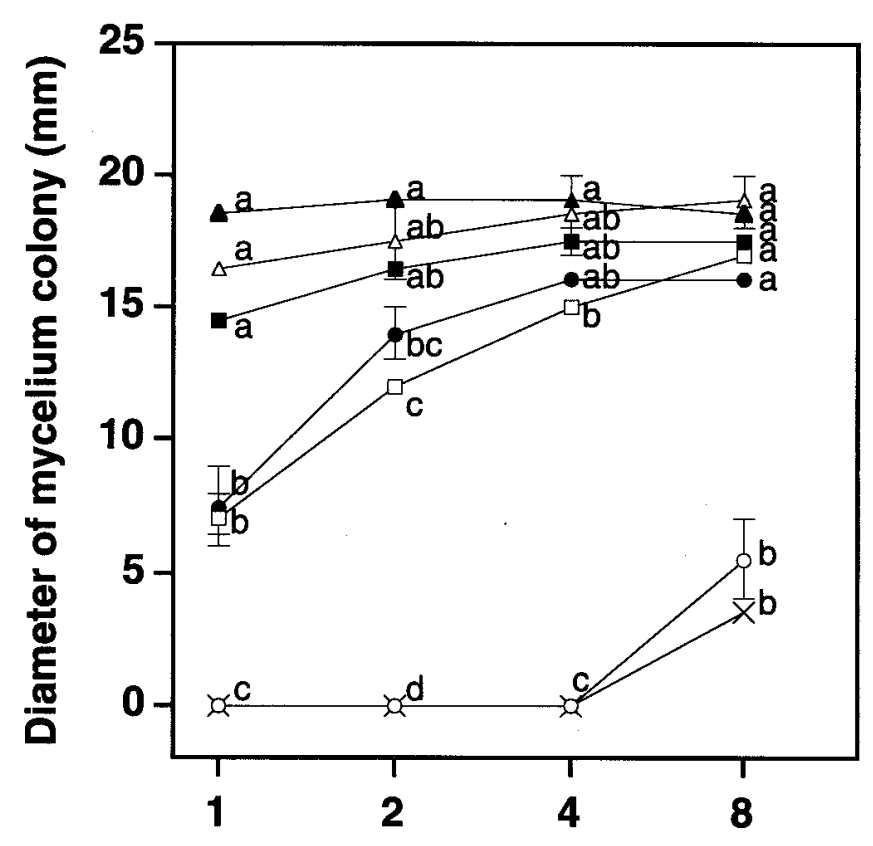

Dilution of culture filtrate (-fold)

Fig. 4. Colony diameter of Colletotrichum dematium treated with each dilution of culture filtrate of Bacillus amyloliquefaciens RC-2 obtained from six media. Undiluted culture filtrate was regarded as onefold. Liquid media used for incubation of RC-2: potato sucrose $(\bullet)$; potato dextrose $(\square)$; King's medium B $(\Delta)$; Luria-Bertani $(\square)$; potato semisynthetic $(O)$; $0.5 \%$ peptone-potato dextrose $(X)$; Sterile distilled water (control) $(\mathbf{\Lambda})$. Each value plotted represents the average of two replicates. Bars represent standard error of the mean. The same letters of each dilution are not significantly different $(P \leq 0.05)$ according to Tukey's test. oryzae (rice blast fungus), and Rosellinia necatrix (mulberry white root rot fungus) was strongly inhibited. PPD broth (0.5\%) alone did not influence bacterial or fungal growth.

Isolation and determination of antifungal compounds from culture filtrate of strain RC-2. Successive bioassay-directed separation of culture filtrate of strain RC-2 by reverse-phase HPLC gave seven antifungal fractions. Each of them corresponded to pure separated peaks of the chromatogram, and they are named compounds one to seven (Fig. 1). ${ }^{1} \mathrm{H}-\mathrm{NMR},{ }^{13} \mathrm{C}-\mathrm{NMR}$, DEPT, C-H COSY, H-H COSY, HOHAHA, and HMBC spectra of compound 1, which gave the largest yield, indicated a chemical structure with cyclic peptide composed of eight amino acids as follows: $\beta$-amino acid with straight-chain $\rightarrow$ Asn $\rightarrow \mathrm{Tyr} \rightarrow \mathrm{Asn} \rightarrow$ $\mathrm{Gln} \rightarrow \mathrm{Pro} \rightarrow \mathrm{Asn} \rightarrow \mathrm{Ser} \rightarrow$. The FAB-MS spectrum of compound one showed an $[\mathrm{M}+\mathrm{H}]^{+}$ion peak at $\mathrm{m} / \mathrm{z}, 1,043$, indicating the molecular weight of 1,042 .

\section{DISCUSSION}

The bacterial strain RC-2, isolated from healthy mulberry leaves, which showed an inhibition activity against anthracnose disease, was identified as B. amyloliquefaciens with API $50 \mathrm{CHB}$ biochemical profiling. This species is similar to B. subtilis (21), and can be distinguished from $B$. subtilis by a slightly higher molecular percent $\mathrm{G}+\mathrm{C}$ content of the DNA (26). Although B. amyloliquefaciens shows properties similar to those of $B$. subtilis, it has not been as frequently reported as an antagonist of various plant diseases. Mari et al. (14) reported that B. amyloliquefaciens $2 \mathrm{TOE}$ reduced the severity of gray mold caused by Botrytis cinerea in pears. They suggested that the antifungal activity of the bacterium was due to competition for nutrients. Yu and Sinclair (32) reported that strain B94 of the bacterium coated on soybean seeds readily colonized the seedling rhizosphere and controlled

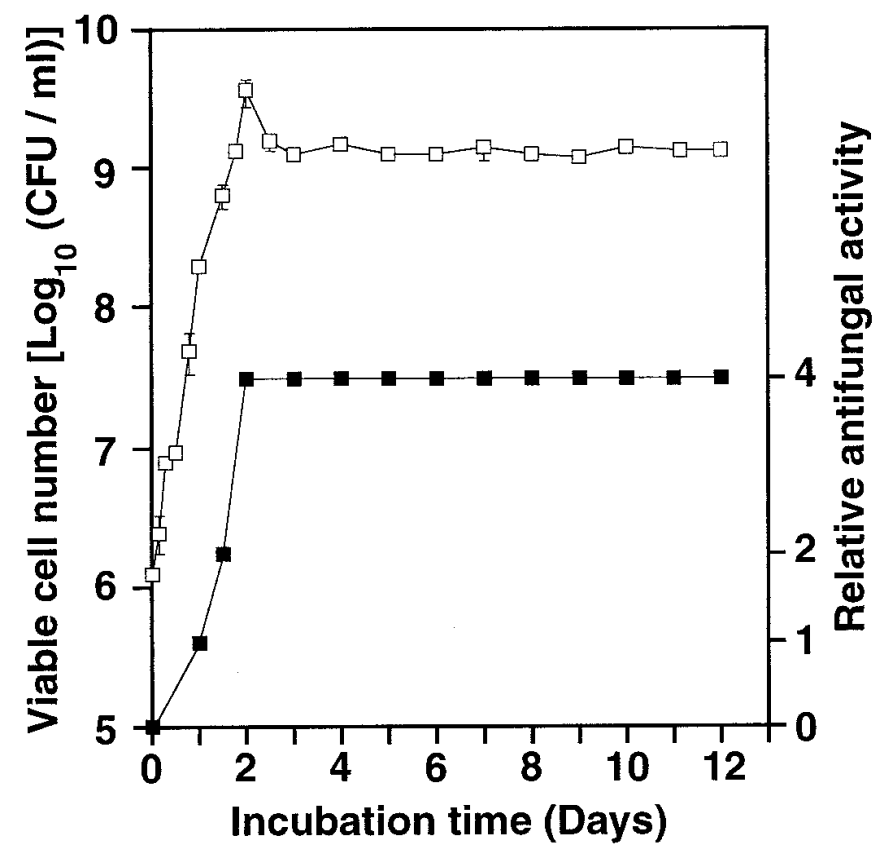

Fig. 5. Antifungal activity of culture filtrate and viable cell numbers of Bacillus amyloliquefaciens $\mathrm{RC}-2$ in each incubation time. RC-2 was shake-cultured in $0.5 \%$ peptone-potato dextrose broth at $25^{\circ} \mathrm{C}$ in the dark. $\square=$ viable cell number of RC-2. Each value plotted represents the average of three replicates. Bars represent standard error of the mean. $\square=$ relative antifungal activity. When maximum dilution ratios of the filtrate showing complete inhibition in mycelial growth by the placing assay are 1,2, or 4, values of the activity are scored as 1,2 , or 4 , respectively. Observation of the activity was performed 3 days after placing filtrate. Each activity plotted represents the data from a single experiment. Experiment of the antifungal activity was replicated three times with the same results. 


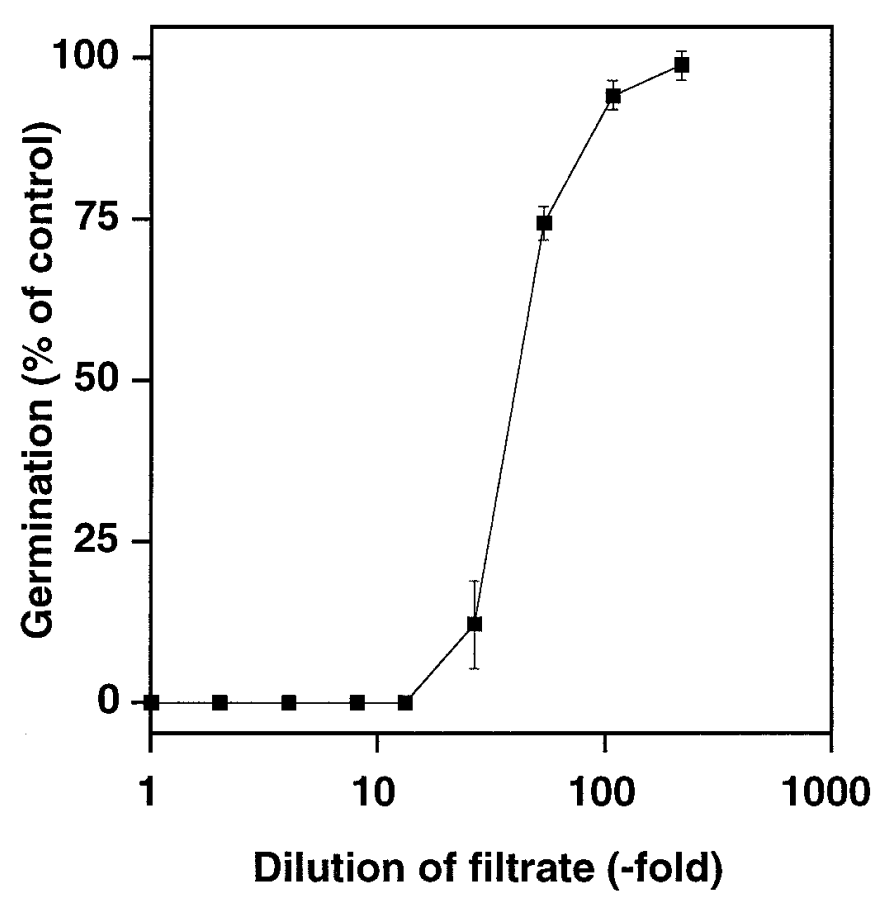

Fig. 6. Germination rate for conidia of Colletotrichum dematium in dilutions of culture filtrate of Bacillus amyloliquefaciens RC-2. An undiluted filtrate was regarded as onefold. Average germination (percent) of conidia not treated with culture filtrate (control) was 80.8 . Each value plotted represents the average of three replicates. Bars represent standard error of the mean.

Rhizoctonia solani. This inhibition is also likely to be due to competition for nutrients rather than to production of antibiotics. However, disease inhibition of mulberry anthracnose by strain RC-2 appears to be due to the antifungal compounds produced in the culture filtrate, because treatment with the bacterial cell-free culture filtrate suppressed the disease. The mechanisms of biological control are generally classified as competition, parasitism or predation, and antibiosis (6). Antibiosis by the strain RC-2 would play a major role in the inhibition of mulberry anthracnose.

Inhibition of anthracnose disease on mulberry leaves by the filtrate was observed when the filtrate was applied before or simultaneously, but not after fungal inoculation, suggesting that the filtrate does not have a therapeutic effect but exerts a preventive effect on the anthracnose disease. Moreover, a strong inhibitory effect on conidial germination of $C$. dematium was observed by the application of the filtrate. Scanning electron microscopy revealed that conidial germination of the fungus was completely inhibited on mulberry leaves pretreated with undiluted culture filtrate of RC-2 (data not shown). These suggest that the preventive effect is due to inhibition of conidial germination on the leaves. The fungus, once germinated and infected into the leaf tissues within $24 \mathrm{~h}$ (27), may not or less suffer from antibiotics in the filtrate. Application of chemical pesticides with biocontrol agents enhances disease inhibition ability in some cases $(2,9,14)$. The application of antifungal compounds in the filtrate of RC-2 with fungicides should be investigated. The products of RC-2 could play a role in disease prevention while fungicides exert a therapeutic effect.

Culture filtrates of strain RC-2 obtained from PSS and $0.5 \%$ PPD liquid cultures showed strong antifungal activity in vitro. In these media, peptone was present at the same concentration. Also, the activity of the filtrates obtained from the PPD broth containing peptone increased as the concentration of peptone increased from 0.01 to $0.5 \%$, suggesting that peptone (a mixture of several kinds of amino acids) is a key nutrient for producing the antifungal compounds in the culture filtrate. Indeed, when RC-2 was incubated in various concentrations (1 to $15 \%$ ) of peptone, each cul- ture filtrate displayed inhibition activity (data not shown). It is generally recognized that many Bacillus spp. produce various antimicrobial peptides as secondary metabolites (20). The antifungal compounds produced by $\mathrm{RC}-2$ may also require peptone or several kinds of amino acids for the biosynthesis of the compounds as substrates.

Antifungal activity of strain RC-2 increased proportionally with the number of bacterial cells, and the activity was maximized in the stationary phase. Members of the genus Bacillus have been reported to produce antibiotics in the late logarithmic or early stationary phase of growth in batch cultures (20). Our results indicate that the bacterial strain is capable of producing antifungal compounds in the earlier logarithmic phase, and the faster the strain arrives at the stationary phase, the more quickly antifungal activity will maximize.

Culture filtrate of RC-2 inhibited mycelial growth of various taxonomically diverse phytopathogenic fungi, in addition to $C$. dematium, indicating that the antifungal compounds in the filtrate exhibit a wide spectrum of antifungal activity. Based on these results, the antifungal substances produced by RC- 2 have potential for the control of several fungal diseases besides mulberry anthracnose. The inhibitory activity of the filtrate against phytopathogenic bacteria depended on the species, and Pseudomonas spp. were more resistant. Slepecky and Hemphill (20) reported that most of the antibiotics produced by Bacillus spp. are active against gram-positive organisms, although there are exceptions. The compounds in the filtrate of RC-2 inhibited gram-negative bacteria as well as the gram-positive bacterium $C$. michiganensis subsp. michiganensis.

Bacillus spp., particularly B. subtilis, produce many kinds of antimicrobial peptide substances such as subtilin (7), bacilysin (24), and mycobacillin (19). In addition, iturin A, a mixture of homologous cyclic peptide, was obtained from B. subtilis (4), and Isogai et al. (8) isolated this antibiotic into eight compounds, named iturin A1 through A8. The chemical characteristics of compound one verified in this study are quite similar to that of iturin A2. The standard sample of iturin A2 was subjected to analysis by HPLC equipped with analytical grade of reversed phase column to identify the chemical structure of compound one. Consequently, retention times and UV-visible spectra (220 to $340 \mathrm{~nm}$ ) for both compounds were completely identical, indicating the chemical structure of compound one was iturin A2. Compounds two through seven would also have similar chemical structures as iturin A2, as indicated by NMR and FAB-MS spectra. Subsequent analytical studies would lead to identification of these compounds. It is reported that iturin secreting $B$. subtilis strain NB 22 could be used as an agent to control soilborne diseases of tomato (16). While further studies, such as verification of toxicity to silkworms (Bombyx mori L.), should be conducted, the compounds produced by the strain RC-2 may also contribute to establish a new control technique of mulberry anthracnose.

\section{LITERATURE CITED}

1. Baker, R. 1968. Mechanisms of biological control of soil-borne pathogens. Annu. Rev. Phytopathol. 6:263-294.

2. Baker, R. 1986. Biological control: An overview. Can. J. Plant Pathol. 8:218-221.

3. Citernesi, A. S., Filippi, C., Bagnoli, G., and Giovannetti, M. 1994. Effect of the antimycotic molecule Iturin A2 secreted by Bacillus subtilis strain M51, on arbuscular mycorrhizal fungi. Microbiol. Res. 149:241-246.

4. Delcambe, L. 1965. L' Iturin. Bull. Soc. Chim. Belg. 74:315-328.

5. Douville, Y., and Boland, G. J. 1992. A note on the antibiotic properties of Bacillus subtilis against Colletotrichum trifolii. Phytoprotection 73:31-36.

6. Fravel, D. R. 1988. Role of antibiosis in the biocontrol of plant diseases. Annu. Rev. Phytopathol. 26:75-91.

7. Gross, E., Kiltz, H. H., and Nebelin, E. 1973. Subtilin IV: The structure of subtilin. Z. Physiol. Chem. 354:810-812.

8. Isogai, A., Takayama, S., Murakoshi, S., and Suzuki, A. 1982. Structures 
of $\beta$-amino acids in antibiotics iturin A. Tetrahedron Lett. 23:3065-3068.

9. Iyozumi, H., Komagata, T., Hirayae, K., Tsuchiya, K., Hibi, T., and Akutsu, K. 1996. Biological control of cyclamen gray mold (Botrytis cinerea) by Serratia marcescens B2. Ann. Phytopathol. Soc. Jpn. 62:559-565.

10. Kelemu, S., and Badel, J. L. 1994. In vitro inhibition of Colletotrichum gloeosporioides and other phytopathogenic fungi by an Amazonian isolate of Bacillus subtilis and its cell-free culture filtrate. Aust. Plant Pathol. 23:41-45.

11. Kimura, K. 1979. The Illustration of Mulberry Diseases in Japan. Kenpakusya, Tokyo.

12. Logan, N. A., and Berkeley, R. C. W. 1981. Classification and identification of members of the genus Bacillus using API tests. Pages 105-140 in: The Aerobic Endospore-Forming Bacteria: Classification and Identification. R. C. W. Berkeley and M. Goodfellow, eds. Academic Press, London.

13. Logan, N. A., and Berkeley, R. C. W. 1984. Identification of Bacillus strains using the API system. J. Gen. Microbiol. 130:1871-1882.

14. Mari, M., Guizzardi, M., and Pratella, G. C. 1996. Biological control of gray mold in pears by antagonistic bacteria. Biol. Control 7:30-37.

15. O'Donnell, A. G., Norrins, J. R., Berkeley, R. C. W., Claus, D., Kaneko, T., Logan, N., and Nozaki, R. 1980. Characterization of Bacillus subtilis, Bacillus pumilus, Bacillus licheniformis, and Bacillus amyloliquefaciens by pyrolysis gas-liquid chromatography, deoxyribonucleic acid-deoxyribonucleic acid hybridization, biochemical tests, and API systems. Int. J. Syst. Bacteriol. 30:448-459.

16. Phae, C. G., Shoda, M., Kita, N., Nakano, M., and Ushiyama, K. 1992. Biological control of crown and root rot and bacterial wilt of tomato by Bacillus subtilis NB22. Ann. Phytopathol. Soc. Jpn. 58:329-339.

17. Podile, A. R., and Prakash, A. P. 1996. Lysis and biological control of Aspergillus niger by Bacillus subtilis AF1. Can. J. Microbiol. 42: 533-538.

18. Ryu, E. 1940. A simple method of differentiation between gram-positive and gram-negative organisms without staining. Kitasato Arch. Exp. Med. 17:58-93.

19. Sengupta, S., Banerjii, A. B., and Bose, S. K. 1971. Г-Glutamyl and D- or L-peptide linkages in mycobacillin, a cyclic peptide antibiotic. Biochem. J. 121:839-846.

20. Slepecky, R. A., and Hemphill, H. E. 1992. The genus Bacillus- nonmedical. Pages 1687-1688 in: The Prokaryotes, 2nd ed. A. Balows, H. G. Truper, M. Dworkin, W. Harder, and K. H. Schleifer, eds. SpringerVerlag, New York.

21. Sneath, P. H. A. 1986. Endospore-forming gram-positive rods and cocci. Pages 1104-1138 in: Bergey's Manual of Systematic Bacteriology, Vol. 2. P. H. A. Sneath, ed. Williams and Wilkins, Baltimore, MD.

22. Swinburne, T. R. 1978. The potential value of bacterial antagonists for the control of apple canker. Ann. Appl. Biol. 89:94-96.

23. Utkhede, R. S., and Smith, E. M. 1992. Promotion of apple tree growth and fruit production by the EBW-4 strain of Bacillus subtilis in apple replant disease soil. Can. J. Microbiol. 38:1270-1273.

24. Walker, J. E., and Abraham, E. P. 1970. Isolation of bacilysin and a new amino acid from culture filtrates of Bacillus subtilis. Biochem. J. 118:557-563.

25. Walker, R., Powell, A. A., and Seddon, B. 1998. Bacillus isolates from the spermosphere of peas and dwarf French beans with antifungal activity against Botrytis cinerea and Pythium species. J. Appl. Microbiol. 84:791-801.

26. Welker, N. E., and Champbell, L. L. 1967. Unrelatedness of Bacillus amyloliquefaciens and Bacillus subtilis. J. Bacteriol. 94:1124-1130.

27. Yoshida, S., and Shirata, A. 1997. Effect of mulberry leaf components on conidial germination of mulberry anthracnose fungus, Colletotrichum dematium, and observation of early infection processes on the mulberry leaf. Bull. Natl. Inst. Seric. Entomol. Sci. 18:79-96.

28. Yoshida, S., and Shirata, A. 1998. Annual development of mulberry anthracnose caused by Colletotrichum dematium in relation to position of leaves in tree. J. Seric. Sci. Jpn. 67:327-332.

29. Yoshida, S., and Shirata, A. 1998. Mulberry anthracnose. Page 195 in: Plant Diseases in Japan. K. Kishi, ed. Zenkoku Nouson Kyouiku Kyoukai, Tokyo.

30. Yoshida, S., and Shirata, A. 1999. Survival of Colletotrichum dematium in soil and infected mulberry leaves. Plant Dis. 83:465-468.

31. Yoshida, S., Shirata, A., Yoshida, S., and Kobayashi, T. 1995. Anthracnose fungi, Colletotrichum dematium, C. acutatum, Glomerella cingulata isolated from diseased mulberry leaves and their pathogenicity. Ann. Phytopathol. Soc. Jpn.61:75-81.

32. Yu, G. Y., and Sinclair, J. B. 1996. Evaluation of Bacillus amyloliquefaciens B94 for control of Rhizoctonia seedling disease on soybeans. (Abstr.) Phytopathology 86(suppl.):S54. 